\title{
REKAM MEDIS SEBAGAI ALAT BUKTI DALAM PENYELESAIAN SENGKETA LAYANAN MEDIS
}

\author{
Abdul Rokhim \\ Fakultas Hukum Universitas Islam Malang \\ Jl. Mayjen Haryono Gg. 10 Kelurahan No.193, Dinoyo, Kec. Lowokwaru, Kota Malang, Jawa \\ Timur 65144 \\ Email: abdul_rokhim@gmail.com
}

\begin{abstract}
A medical record is a file that contains notes and documents about the patient's identity, examination, treatment, actions and other services that have been given to the patient. So need to know how the concept and content of medical record According to the legislation in the medical field (health)? How is the medical record function as a tool of evidence in the settlement of medical services disputes? How is the position of medical record as a tool of KUHAP? Using normative juridical methods of research. Formly, medical record as a tool of evidence in the settlement of medical services disputes has a dual function, namely as a tool of evidence of the expert in written form and proof of letter tools. Materically, the position of medical record as an instrument of evidence of the expert and as a means of proof of letter is a tool of free evidence, meaning that the judge is not bound to believe the truth of the medical record, he can believe and use the evidence or not, completely dependent on the free judgment of the judge.
\end{abstract}

Key Word: Medical Record, Evidence, Medical Services

\begin{abstract}
ABSTRAK
Rekam medis adalah berkas yang berisi catatan dan dokumen tentang identitas pasien, pemeriksaan, pengobatan, tindakan dan pelayanan lain yang telah diberikan kepada pasien. Sehingga perlu mengetahui bagaimana konsep dan isi rekam medis menurut peraturan perundang-undangan di bidang medis (kesehatan)? bagaimana fungsi rekam medis sebagai alat bukti dalam penyelesaian sengketa layanan medis? bagaimana kedudukan rekam medis sebagai alat bukti menurut Undang-undang Nomor 8 Tahun 1981 tentang Acara Pidana (KUHAP)? Menggunakan metode penelitian yuridis normatif. Secara formil, rekam medis sebagai alat bukti dalam penyelesaian sengketa layanan medis mempunyai fungsi ganda, yaitu sebagai alat bukti keterangan ahli dalam bentuk tertulis dan alat bukti surat. Secara materiil, kedudukan rekam medis sebagai alat bukti keterangan ahli maupun sebagai alat bukti surat merupakan alat bukti bebas, artinya hakim tidak terikat untuk meyakini kebenaran isi rekam medis, ia bisa meyakini dan menggunakan alat bukti itu atau tidak, sepenuhnya bergantung pada penilaian bebas dari hakim.
\end{abstract}

Kata Kunci: Rekam Medis; Alat Bukti; Layanan Medis

\section{PENDAHULUAN}

Pembangunan bidang kesehatan pada dasarnya menyangkut semua segi kehidupan, baik fisik, mental maupun sosial. Hal ini sesuai dengan makna "sehat" (health) menurut World Health Organization (WHO) yang meliputi kesehatan fisik, mental dan sosial (physic, mental, and social well-being) bagi setiap orang. Dalam perkembangannya, pembangunan bidang kesehatan selama ini telah terjadi perubahan orientasi baik menyangkut "tata nilai" maupun "pemikiran" masyarakat yang disebabkan oleh faktor politik, ekonomi, agama, sosial-budaya, serta 
ilmu pengetahuan dan teknologi yang kontraktual yang sifatnya sederajat berkembang di masyarakat.

(horizontal).

Perubahan orientasi tersebut sejalan

Ada perbedaan yang mendasar antara pola dengan pergeseran pandangan masyarakat mengenai hubungan antara dokter dan pasien.

Semula masyarakat beranggapan bahwa dokter dalam menjalankan tugas profesinya tidak mungkin salah, oleh karena itu biasanya pasien sepenuhnya percaya pada kemampuan dokter untuk menyembuhkan penyakitnya. Model hubungan antara dokter dan pasien seperti ini sifatnya Vertikal-Paternalistik. ${ }^{1}$ Hubungan antara dokter dan pasien dalam pelayanan medik sepenuhnya berdasarkan kepercayaan (fiduciary relationship). Dalam arti, pasien pasrah dan percaya sepenuhnya kepada dokter yang memberikan tindakan medik (pengobatan) atas dirinya. Akan tetapi, berkat perkembangan ilmu pengetahuan dan teknologi, termasuk isu mengenai Hak Asasi Manusia (HAM), telah mempengaruhi alam pikiran manusia. Dewasa ini dokter harus menjelaskan dulu apa yang hendak dilakukan terhadap diri pasien, apa risiko dan akibatnya jika tidak dilakukan. Masyarakat (in casu: pasien) semakin kritis, tahu dan menyadari akan hak-hak serta kewajiban-kewajibannya, sehingga hubungan antara dokter dan pasien dipandang sebagai suatu hubungan hubungan vertikal yang paternalistik dengan pola hubungan horisontal yang kontraktual. Semula pada masyarakat tradisional yang masih bersifat paternalistik berpandangan bahwa hubungan antara pemberi jasa kesehatan (dokter) dengan penerima jasa kesehatan (pasien) kedudukannya vertikal (atas-bawah), dalam arti kedudukan pasien berada di bawah tenaga kesehatan (untergeordnet). Namun, pada masyarakat modern yang lebih mengedepankan kontrak dalam hubungan-hubungan sosial atau bisnis, maka kedudukan antara pemberi jasa kesehatan (dokter) dengan penerima jasa pelayanan kesehatan (pasien) sifatnya sederajat (nebengeordnet) atau horisontal. $^{2}$

Dalam hubungan kontraktual dokter setuju mengupayakan kesembuhan pasien secara cermat dan sungguh-sungguh, sedangkan pasien menyetujui dilakukannya tindakan medik tertentu oleh dokter kepadanya dengan (atau tanpa) imbalan sejumlah uang tertentu. Oleh karena hubungan antara dokter dan pasien tersebut merupakan hubungan atas dasar perjanjian (kontrak), maka syarat-syarat sahnya perjanjian sebagaimana yang diatur dalam pasal 1320 Kitab Undang-undang Hukum Perdata atau Burgerlijk Wetboek (BW) berlaku dalam hubungan tersebut.

\footnotetext{
1 Robert T. Francoeur, (2010), Biomedical Ethics: A Guide to Decision Making, A Wiley Medical Publication, John Wiley \& Sons, New York, Chicester, Brisbane, Toronto, Singapore, 1983, hlm. 74. Lihat juga, J. Gunadi, Hukum Medik (Medical Law), Cet. Ke-4, Balai Penerbit FKUI, Jakarta, hlm. 96.

2 Hermien Hadiati Koeswadji, (1998), Hukum Kedokteran (Studi tentang Hubungan Hukum dalam mana Dokter sebagai Salah Satu Pihak), Citra Aditya Bakti, Bandung, hlm. 46.
} 
Karena hubungan hukum antara dokter dan pasien lahir karena perjanjian, maka apabila pasien merasa dirugikan akibat tindakan medik tertentu yang tidak sesuai dengan isi perjanjian, maka ia dapat mengajukan gugatan wanprestasi berdasarkan Pasal 1243 KUH Perdata. Sebaliknya, apabila pasien merasa dirugikan akibat kesalahan atau kelalaian dokter yang lahir karena perbuatan melanggar hukum (onrechtmatige daad), misalnya karena kelalaian dokter dalam melakukan tindakan medis (malpraktik), maka pasien atau kelaurganya dapat menggugatnya berdasarkan Pasal 1365 KUH Perdata

Permasalahannya adalah baik gugatan atas dasar wanprestasi atau dugaan perbuatan melanggar hukum. Penggugat (pasien) harus dapat membuktikan kesalahan atau kelalaian tergugat (dokter) yang mengakibatkan kerugian terhadap pasien. Hal ini terkait dengan persoalan pembuktian unsur kesalahan dan alat-alat bukti yang dapat digunakan untuk membuktikan unsur kesalahan itu. Di bidang kesehatan (kedokteran) dikenal 4 (empat) macam alat bukti surat yang dapat membantu untuk membuktikan ada atau tidak adanya kesalahan atau kelalaian dokter dalam melaksanakan tugas profesinya, yaitu:

(1) kartu berobat (medical card);
(2) persetujuan tindakan medis (informed consent);

(3) rekam medis (medical record);

(4) resep dokter (medical recipe).

Dalam tulisan ini sengaja dipilih dan dibatasi pada alat bukti rekam medis, karena rekam medis merupakan salah satu sarana yang oleh peraturan perundang-undangan disyaratkan (diwajibkan) dalam melaksanakan tugas profesi kedokteran yang berfungsi sebagai dasar untuk merencanakan perawatan bagi pasien dan berisi catatan mengenai penyakit yang diderita oleh pasien serta pengobatan yang dilakukan sebagai dasar untuk mengevaluasi perawatan medis yang telah diberikan kepada pasien. ${ }^{3}$ Di samping itu, rekam medis yang memuat data pelayanan medis, mulai dari tahap anamnese, diagnosis, persetujuan tindakan medik (informed consent), sampai dengan terapi yang dilakukan oleh dokter kepada pasiennya, secara hukum dapat berfungsi sebagai alat bukti dalam proses persidangan di pengadilan, khususnya dalam kasus malpraktik medis (medical malpractice).

Begitu pentingnya fungsi rekam medis bagi dokter ditinjau dari aspek hukum, maka rekam medis yang dibuat oleh dokter sesuai standar dan disimpan dengan baik oleh dokter atau rumah sakit secara hukum dapat digunakan sebagai alat bukti dalam pembelaannya di pengadilan bahwa tindakan medis yang telah

\footnotetext{
3 Kadir Sanusi, (1995), Segi-segi Tanggungjawab Hukum Rumah Sakit dalam Kaitannya dengan Hubungan Dokter-Pasien, Surabaya; Disertasi, Program Pascasarjana Universitas Airlangga, hlm. 127.
} 
dilakukannya memenuhi standar profesi. Sebaliknya, bagi Jaksa Penuntut Umum apabila ternyata dalam hubungan pelayanan medis tidak ada rekam medis yang dibuat oleh dokter atau dibuat tidak sesuai standar yang ditentukan dalam peraturan, maka hal itu bisa menyudutkan atau merugikan dokter atau rumah sakit, bahkan dengan bukti rekam medis yang tidak dibuat atau dibuat tetapi tidak sesuai standar, dokter dapat dituntut melakukan tindakan yang tidak profesional (unprofessional conduct) atau melanggar standar profesi. ${ }^{4}$

Berdasarkan latar belakang masalah tersebut di atas, permasalahan yang diteliti dan dianalisis dalam tulisan ini adalah bagaimana konsep dan isi rekam medis menurut peraturan perundang-undangan di bidang medis (kesehatan)? bagaimana fungsi rekam medis sebagai alat bukti dalam penyelesaian sengketa layanan medis? bagaimana kedudukan rekam medis sebagai alat bukti menurut Undang-undang Nomor 8 Tahun 1981 tentang Acara Pidana (KUHAP)? Penelitian ini termasuk jenis penelitian hukum normatif, yang menggunakan pendekatan konsep (conceptual approach) dan pendekatan peraturan perundang-undangan (statute approach). Penelitian ini menggunakan data sekunder berupa bahan hukum primer (peraturan perundang-undangan) dan bahan hukum sekunder (bahan pustaka). ${ }^{5}$ Bahanbahan hukum tersebut setelah dikumpulkan dan diklasifikasi, kemudian dianalisis secara kualitatif dengan menggunakan metode penafsiran hukum.

\section{PEMBAHASAN}

\section{Konsep dan Isi Rekam Medis}

Istilah "Rekam Medis" atau "Rekam Medik" berasal dari bahasa Inggris Medical Record". Di Indonesia, selain istilah "Rekam Medis" juga pernah digunakan istilah Status Pasien yang berasal dari bahasa Belanda "Patienten Status". Di Rumah Sakit Cipto Mangunkusumo (RSCM) Jakarta, digunakan istilah "Dokumen Medis" yang sebenarnya memiliki pengertian lebih luas dari pada rekam medis. ${ }^{6}$ Karena, dokumen medis tidak hanya berupa rekam medis, termasuk juga kartu medis, persetujuan tindakan medis, resip medis, dan lain-lain. Dengan perkataan lain, rekam medis hanya merupakan salah satu dari dokumen medis.

Di Indonesia pengaturan mengenai rekam medis telah diatur dalam hukum positif melalui Keputusan Menteri Kesehatan RI Nomor 031/Bihup/1972 tentang kewajiban

\footnotetext{
4 Syahrul Machmud, (2008), Penegakan Hukum dan Perlindungan Hukum bagi Dokter yang Diduga Melakukan Medikal Malpraktek, Bandung; Mandar Maju, hlm. 117.

5 Menurut Ronny Hanitijo Soemitro, (1994), Metodologi Penelitian Hukum dan Jurimetri, Cet. V, Jakarta; Ghalia Indonesia, hlm. 11-12.

6 Rio Christiawan, (2013), Aspek Hukum Kesehatan, Universitas Atmajaya, Yogyakarta, 2003, hlm. 12. Lihat juga, Moh. Hatta, Hukum Kesehatan dan Sengketa Medik, Yogyakarta; Liberty, 2013, hlm. 83.
} 
Rumah Sakit untuk mengerjakan medical recording dan reporting serta hospital statistic. Keputusan tersebut diikuti dengan Keputusan Menteri Kesehatan RI Nomor 034/Bihup/1972 tentang Perencanaan dan Pemeliharaan Rumah Sakit, yang pada pasal 3 ayat (2)-nya mengatur mengenai kewajiban Rumah Sakit untuk membina rekam medis berdasarkan ketentuan-ketentuan yang telah ditetapkan. Selanjutnya, pada tahun 1988, Ikatan Dokter Indonesia (IDI) mengeluarkan Surat Keputusan Pengurus Besar IDI Nomor 315/PB/A.4/88 yang pada butir 1 menyebutkan bahwa "Rekam Medis/Kesehatan adalah rekam dalam bentuk tulisan atau gambaran aktivitas pelayanan yang diberikan oleh pemberi layanan medis/kesehatan kepada seorang pasien".

Pengaturan mengenai rekam medis, selanjutnya diatur melalui Peraturan Menteri Kesehatan RI Nomor 749a/Menkes/Per/XII/1989 tentang Rekam Medis (Medical Record), yang pada pasal 1 huruf a menyebutkan bahwa: "rekam medis memiliki pengertian sebagai berkas yang berisikan catatan dan dokumen tentang identitas pasien, pemeriksaan, pengobatan, indakan, dan pelayanan lain pada pasien pada sarana pelayanan kesehatan".

Pengaturan lebih kuat mengenai rekam medis dapat kita jumpai dalam Pasal 46 ayat (1) Undang-Undang Nomor 29 Tahun 2004 tentang Praktik Kedokteran (UU Praktik Kedokteran) yang mengatakan bahwa setiap dokter atau dokter gigi dalam menjalankan praktik kedokteran wajib membuat rekam medis.

Arti rekam medis menurut Penjelasan Pasal 46 ayat (1) UU Praktik Kedokteran adalah berkas yang berisikan catatan dan dokumen tentang identitas pasien, pemeriksaan, pengobatan, tindakan, dan pelayanan lain yang telah diberikan kepada pasien. Pengertian rekam medis menurut Penjelasan ini kemudian dituangkan sama persis dalam Pasal 1 angka 1 Peraturan Menteri Kesehatan RI Nomor 269/Menkes/Per/III/2008 tentang Rekam Medis, yang menyatakan bahwa rekam medis adalah berkas yang berisikan catatan dan dokumen tentang identitas pasien, pemeriksaan, pengobatan, tindakan dan pelayanan lain yang telah diberikan kepada pasien.

Lebih lanjut, dalam Pasal 47 UU Praktik Kedokteran diatur bahwa:

(1) Dokumen rekam medis sebagaimana dimaksud dalam Pasal 46 merupakan milik dokter, dokter gigi, atau sarana pelayanan kesehatan, sedangkan isi rekam medis merupakan milik pasien.

(2) Rekam medis sebagaimana dimaksud pada ayat (1) harus disimpan dan dijaga kerahasiaannya oleh dokter atau dokter gigi dan pimpinan sarana pelayanan kesehatan. 
(3) Ketentuan mengenai rekam medis sebagaimana dimaksud pada ayat (1) dan ayat (2) diatur dengan Peraturan Menteri.

Tentang kewajiban dokter atau dokter gigi membuat rekam medis, sebagai tindak lanjut dari ketentuan pasal 46 ayat (1) UU Praktik Kedokteran, Menteri Kesehatan telah menerbitkan Peraturan Menteri Kesehatan RI Nomor 1419/Menkes/Per/X/2005 tentang Penyelenggaraan Praktik Kedokteran, yang pada pasal 16 ayat (1)-nya juga menyebutkan bahwa dokter atau dokter gigi dalam pelaksanaan praktik kedokteran wajib membuat rekam medis. Bagi dokter atau dokter gigi yang tidak menyelenggarakan (baca: membuat dan menyimpan) rekam medis, menurut pasal 79 huruf b UU Praktik Kedokteran, dapat dijatuhi pidana kurungan paling lama 1 (satu) tahun atau denda paling banyak Rp 50.000.000,- (lima puluh juta rupiah). ${ }^{7}$

Selanjutnya, mengenai isi rekam medis, dengan mengacu pada definisi rekam medis sebagaimana diatur pada pasal 46 ayat (1) UU Praktik Kedokteran jo. Pasal 1 angka 1 Peraturan Menteri Kesehatan RI Nomor 269/Menkes/Per/III/2008 tentang Rekam Medis, berisi catatan dan dokumen tentang identitas pasien, pemeriksaan, pengobatan, tindakan dan pelayanan lain yang telah diberikan kepada pasien. Dalam hal terjadi kesalahan dalam melakukan pencatatan pada rekam medis, berkas dan catatan tidak boleh dihilangkan atau dihapus dengan cara apapun. Perubahan catatan atau kesalahan dalam rekam medis hanya dapat dilakukan dengan pencoretan dan dibubuhi paraf petugas yang bersangkutan, dalam hal ini dokter atau dokter gigi atau tenaga kesehatan lain yang memberikan pelayanan langsung kepada pasien (pasal 46 ayat (2) UU Praktik Kedokteran dan Penjelasannya).

Secara rinci isi rekam medis diatur lebih lanjut pada Pasal 3 Permenkes Nomor 269/Menkes/Per/III/2008 adalah sebagai berikut:

(1) Isi rekam medis untuk pasien rawat jalan pada sarana pelayanan kesehatan sekurang-kurangnya memuat:

a. identitas pasien;

b. tanggal dan waktu;

c. hasil anamnesis, mencakup sekurangkurangnya keluhan dan riwayat penyakit;

d. hasil pemeriksaan fisik dan penunjang medik;

e. diagnosis;

f. rencana penatalaksanaan;

g. pengobatan dan/atau tindakan;

h. pelayanan lainyang telah diberikan kepada pasien;

7 Bandingkan dengan Permenkes RI Nomor 749a/Menkes/Per/XII/1989, yang (hanya) memberikan sanksi administrasi mulai dari teguran lisan sampai pencabutan izin praktik bagi dokter atau dokter gigi yang tidak membuat rekam medis. 
i. untuk pasien kasus gigi dilengkapi dengan odontogram klinik; dan

j. persetujuan tindakan bila diperlukan.

(2) Isi rekam medis untuk pasien rawat inap dan perawatan satu hari sekurangkurangnya memuat:

a. identitas pasien;

b. tanggal dan waktu;

c. hasil anamnesis, mencakup sekurangkurangnya keluhan dan riwayat penyakit;

d. hasil pemerisaan fisik dan penunjang medis;

e. diagnosis:

f. rencana penatalaksanaan;

g. pengobatan dan/atau tindakan;

h. persetujuan tindakan bila diperlukan;

i. catatan observasi klinis dan hasil pengobatan.

j. ringkasan pulang (discharge summary);

k. nama dan tanda tangan dokter, dokter gigi, atau tenaga kesehalan tertentu yang memberikan pelayanan kesehatan;

1. pelayanan lain yang dilakukan oleh tenaga kesehatan tertentu; dan

m. untuk pasien kasus gigi dilengkapi dengan odontogram klinik.

(3) Isi rekam medis untuk pasien gawat darurat sekurang-kurangnya memuat:

a. identitas pasien;

b. kondisi saat pasien tiba di sarana pelayanan kesehatan; c. identitas pengantar pasien;

d. tanggal dan waktu;

e. hasil anamnesis, mencakup sekurangkurangnya keluhan dan riwayat penyakit;

f. hasil pemeriksaan fisik dan penunjang medis;

g. diagnosis;

h. pengobatan dan/atau tindakan;

i. ringkasan kondisi pasien sebelum meninggalkan pelayanan unit gawat darurat dan rencana tindak lanjut;

j. nama dan tanda tangan dokter, dokter gigi, atau tenaga kesehatan tertentu yang memberikan pelayanan kesehatan;

k. sarana transportasi yang digunakan bagi pasien yang akan dipindahkan ke sarana pelayanan kesehatan lain; dan

1. pelayanan lain yang telah diberikan kepada pasien.

(4) Isi rekam medis pasien dalam keadaan bencana, selain memenuhi ketentuan sebagaimana dimaksud pada ayat (3) ditambah denqan:

a. jenis bencana dan lokasi di mana pasien ditemukan;

b. kategori kegawatan dan nomor pasien bencana masal; dan

c. identitas yang menemukan pasien;

(5) Isi rekam medis untuk pelayanan dokter spesialis atau dokter gigi spesialis dapat dikembangkan sesuai dengan kebutuhan. 
(6) Pelayanan yang diberikan dalam ambulans atau pengobatan masal dicatat dalam rekam medis sesuai ketentuan sebagaimana diatur pada ayat (3) dan disimpan pada sarana pelayanan kesehatan yang merawatnya.

Rekam medis merupakan himpunan halhal yang berhubungan dengan riwayat penyakit dan perawatan/pengobatan pasien. Rekam medis memuat kumpulan data ilmiah yang diperoleh dari berbagai sumber yang dikoordinasikan dalam suatu dokumen dan dapat dimanfaatkan untuk bermacam-macam keperluan, baik untuk keperluan yang bersifat pribadi maupun tidak, khususnya bagi pasien, dokter atau institusi dimana pasien dirawat, atau bagi keperluan ilmiah kedokteran, serta masyarakat. ${ }^{8}$ Dengan demikian, rekam medis merupakan dokumen rahasia milik pribadi pasien. Ini berarti, dalam hal keluarga pasien atau pihak ketiga ingin melihat isi rekam medis maka mereka harus terlebih dahulu mendapatkan izin tertulis dari pasien atau kuasanya. Setelah mendapatkan izin dari pasien, maka isi rekam medis dapat diperlihatkan oleh Rumah Sakit atau dokter yang merawat pasien tersebut, itupun hanya dalam bentuk ringkasan atau fotokopi dengan menutup bagian tertentu yang berkaitan dengan:

(1) Catatan tentang orang ketiga, karena ini bukan milik pasien, keterangan medis tentang pihak ketiga ini biasanya berhubungan dengan penyakit heritage seperti kanker atau diabetes melitus.

(2) Personal notes, yaitu catatan pribadi dari dokter sendiri, misalnya mengenai kemungkinan/perkiraan tentang hal-hal yang berhubungan dengan pasien atau rencana tertentu dalam terapi/diagnosis untuk pasien. $^{9}$

Menurut pasal 5 ayat (1) Permenkes RI Nomor 269/Menkes/Per/III/2008, “Setiap dokter atau dokter gigi dalam menjalankan praktik kedokteran wajib membuat rekam medis". Setiap pencatatan ke dalam rekam medis harus dibubuhi nama dan tanda tangan petugas yang memberikan pelayanan medis. Pemberian tanda tangan ini penting, karena dengan tanda tangan itu berarti ia telah mengakui kebenaran isi rekam medis yang ditandatanganinya. Di samping itu, bisa saja terjadi dokter memberi perintah melalui telepon kepada perawat yang menerima perintah tersebut, dan untuk menghindari kesalahan maka perawat itu harus membaca ulang kepada dokter mengenai apa yang diperintahkan itu, jika ada kesalahan maka dokter dapat segera memperbaikinya (pasal 5 ayat (5).

Fungsi Rekam Medis sebagai Alat Bukti dalam Penyelesaian Sengketa Layanan Medis

\footnotetext{
8 Kadir Sanusi, op. cit., hlm. 216.

9 Fred Ameln, (1991), Kapita Selekta Hukum Kedokteran, Jakarta; Grafikatama, hlm. 7.
} 
Rekam medis memiliki peran dan fungsi yang sangat penting dalam kegiatan pelayanan kesehatan atau dalam praktik kedokteran. Dalam Canadian Council on Hospital Acreditation disebutkan:

"Medical records are an important tool in the practice of medicine. They serve as a basis for planning patient care; they provide a means of communation between the attending physician and other physicians and with nurses and other professional groups contributing to the patient's care; the furnish documentary evidence of the course of the patient's illness, treatment and response to treatment". ${ }^{10}$

Begitu pentingnya peranan rekam medis dan melekat erat dengan kegiatan pelayanan medis atau pelayanan kedokteran (medical services), bahkan dapat dipandang sebagai orang ketiga yang hadir pada saat dokter menerima pasien. ${ }^{11}$ Rekam medis juga berfungsi untuk mengingatkan dokter tentang keadaan, pemeriksaan, diagnosa, dan kesimpulan mengenai penyakit yang diderita oleh pasiennya. Termasuk mengenai terapi atau pengobatan yang pernah dilakukannya. Hal ini dapat membantu dokter untuk pengobatan selanjutnya. Apakah akan diteruskan dengan terapi atau pengobatan yang pernah diberikan atau harus diganti dengan terapi atau pengobatan lain. Karena itu, rekam medis yang dibuat dan dirawat dengan baik sangat penting dalam sistem pelayanan kesehatan yang diselenggarakan di rumah sakit atau di tempat-tempat praktik pelayanan kesehatan yang lain, termasuk praktik pelayanan kesehatan pribadi.

M. Yusuf Hanafiah dan Amri Amir menyebutkan beberapa fungsi dan kegunaan rekam medis sebagai berikut: ${ }^{12}$

1. sebagai alat kemunikasi antara dokter dan tenaga kesehatan lainnya yang ikut ambil bagian dalam memberi pelayanan pengobatan dan perawatan pasien;

2. merupakan dasar untuk merencanakan pengobatan/perawatan yang harus diberikan dokter kepada pasien;

3. sebagai alat bukti tertulis atas segala pelayanan, perkembangan penyakit dan pengobatan selama pasien berkunjung/dirawat di rumah sakit;

4. sebagai dasar analisis, studi, evaluasi terhadap mutu pelayanan yang diberikan kepada pasien;

5. melindungi kepentingan hukum bagi pasien, rumah sakit, maupun dokter dan tenaga kesehatan lainnya;

\footnotetext{
${ }^{10}$ Sebagaimana dikutip dalam Soerjono Soekanto dan Herkutanto, (1987), Pengantar Hukum Kesehatan, Bandung; Remaja Karya, hlm. 146.

${ }^{11}$ M. Yusuf Hanafiah dan Amri Amir, (1999), Etika Kedokteran dan Hukum Kesehatan, Jakarta; Buku Kedokteran EGC, hlm. 55.

${ }^{12}$ Ibid., hlm. 60-61.
} 
6. menyediakan data khusus lainnya yang sangat berguna untuk keperluan penelitian dan pendidikan;

7. sebagai dasar dalam perhitungan biaya pembayaran pelayanan medis pasien;

8. menjadi sumber ingatan yang harus didokumentasikan, serta sebagai bahan pertanggungjawaban dan laporan.

Dengan meningkatnya kerumitan sistem pelayanan kesehatan di Indonesia, Rekam Medis semakin penting kegunaannya. Menurut pasal 14 Permenkes RI Nomor 749a/Menkes/Per/XII/1989, rekam medis dapat dipakai sebagai:

1. Dasar pemeliharaan kesehatan dan pengobatan pasien;

2. Bahan pembuktian dalam perkara hukum;

3. Bahan penelitian dalam pendidikan;

4. Dasar pembayaran biaya pelayanan kesehatan; dan

5. Bahan untuk menyiapkan statistik kesehatan.

Selanjutnya, menurut Pasal 10 ayat (1) Permenkes RI Nomor 269/ Menkes/Per/XII/2008 menegaskan bahwa informasi tentang isi rekam medis berupa identitas, diagnosis, riwayat pemeriksaan, dan riwayat pengobatan dapat harus dijaga kerahasiaannya oleh dokter, dokter gigi, tenaga kesehatan tertentu, petugas pengelola dan pimpinan sarana pelayanan kesehatan.
Menurut pasal 10 ayat (2) Permenkes RI Nomor 269/Menkes/Per/XII/2008, informasi itu secara hukum dapat dibuka dalam hal:

a. untuk kepentingan kesehatan pasien;

b. memenuhi permintaan aparatur penegak hukum dalam rangka penegakan hukum atas perintah pengadilan;

c. permintan dan/atau persetujuan pasien;

d. permintaan institusi/lembaga berdasarkan ketentuan perundang-undangan; dan

e. untuk kepentingan penelitian, pendidikan dan audit medis, sepanjang tidak menyebutkan identitas pasien.

Sejalan dengan kegunaan rekam medis seperti tersebut dalam pasal 10 Permenkes RI Nomor 269/Menkes/Per/XII/2008, fungsi rekam medis menurut Koeswadji meliputi: Administration, Legal, Financial, Education, dan Documentation (disingkat: ALFRED). ${ }^{13}$ Hal ini berarti, rekam medis selain berfungsi sebagai sarana administrasi antara dokterpasien, juga dapat berfungsi sebagai sarana komunikasi dan informasi. Fungsi legal dari rekam medis adalah sebagai alat bukti bila terjadi sengketa medis antara dokter dan pasien. Rekam medis sebagai sarana finansial karena dapat digunakan untuk menghitung biaya perawatan dan pengobatan yang diperlukan oleh pasien. Selain itu rekam medis juga dapat merupakan lembar pengumpul data

\footnotetext{
${ }^{13}$ Hermien Hadiati Koeswadji, (1998), loc. cit. Lihat juga, Hendrik, Etika dan Hukum Kesehatan, Jakarta; Penerbit Buku Kedokteran EGC, 2011, hlm. 86. Lihat juga, Sutarno, (2014), Hukum Kesehatan: Euthanasia, Keadilan dan Hukum Positif di Indonesia, Malang; Setara Press, hlm. 63-64.
} 
untuk research (penelitian) dan education (pendidikan) yang dapat membantu anak didik untuk dapat memecahkan masalah yang dihadapi secara ilmiah. Akhirnya, rekam medis juga berfungsi sebagai alat dokumentasi dan sarana untuk menjamin kesehatan.

Dengan demikian, berkas rekam medis yang terisi dengan baik mempunyai banyak kegunaan mencakup aspek-aspek administrasi, hukum, keuangan, penelitian dan pendidikan, serta administrasi. Oleh karena itu, kelengkapan dan keakuratan isi rekam medis yang dibuat oleh dokter merupakan instrumen hukum penting yang dapat digunakan sebagai alat bukti oleh dokter (tenaga medis) untuk melindungi dirinya dalam menghadapi tuntutan pidana atau gugatan perdata dalam sengketa layanan medis di pengadilan.

\section{Kedudukan Rekam Medis sebagai Alat Bukti Menurut KUHAP}

Secara yuridis, rekam medik merupakan salah satu alat bukti yang dapat digunakan dalam proses penegakan hukum. Karena itu, kegagalan atau ketidaksempurnaan dalam pengisian berkas rekam medis dapat berakibat fatal bagi tenaga medik, rumah sakit, dan pasien. Mengingat rekam medis merupakan alat bukti utama yang digunakan oleh pengadilan dalam menyelesaikan sengketa medis yang melibatkan dokter dan pasien.
Alat bukti dalam konteks hukum pidana formil merupakan suatu alat (sarana) yang digunakan untuk membantu menemukan atau mencari kebenaran suatu hal, atau menurut konsepsi hukum pidana, merupakan alat untuk membuktikan kebenaran yang sejati (kebenaran materiil). Kebenaran sejati yang dicari atau dibuktikan adalah tentang keadaankeadaan tertentu yang telah berlalu pada saat peristiwa terjadi.

Dalam hubungannya dengan masalah pembuktian, pasal 14 Peraturan Menteri Kesehatan RI Nomor 749a/Menkes/Per/XII/1989 tentang Rekam Medis, menegaskan bahwa rekam medis dapat digunakan sebagai alat bukti dalam persidangan. Sedangkan macammacam alat bukti (yang sah) menurut pasal 184 Undang-undang Nomor 8 Tahun 1981 tentang Hukum Acara Pidana, yang lazim disebut Kitab Undang-undang Hukum Acara Pidana (KUHAP), meliputi:
(a) keterangan saksi;
(b) keterangan ahli;
(c) surat;
(d) petunjuk; dan
(e) keterangan terdakwa.

Dilihat dari urut-urutan penyebutan alatalat bukti berdasarkan pasal 184 KUHAP di atas, menunjukkan bahwa pembuktian dalam perkara pidana lebih menitikberatkan pada keterangan saksi dan keterangan ahli daripada alat bukti surat, petunjuk maupun keterangan terdakwa. Hal ini bisa dimengerti, karena seseorang yang melakukan perbuatan pidana 
selalu berusaha mengingkari bukti-bukti surat, petunjuk, dan keterangan terdakwa, sehingga bukti harus dicari dari keterangan orang-orang yang secara kebetulan melihat atau mengalami kejadian-kejadian yang merupakan perbuatan pidana itu (keterangan saksi); atau mencari bukti dari keteranganketerangan orang yang mempunyai keahlian khusus berkenaan dengan pembuktian dalam perkara perdata yang lebih mengutamakan alat bukti tulisan, ${ }^{14}$ karena memang tujuannya untuk mencari kebenaran formal.

Dalam hukum (acara) pidana, Indonesia menganut asas pembuktian negatif, yang berarti bahwa seseorang tidak cukup untuk dinyatakan terbukti melakukan tindak pidana berdasarkan alat-alat bukti yang menurut undang-undang (dalam hal ini pasal 184 KUHAP) secara komulatif, melainkan juga masih harus disertai dengan keyakinan hakim. ${ }^{15}$

Dalam kasus-kasus dimana dokter merupakan salah satu pihak (misalnya kasus malpraktek), salah satu kendala yang dihadapi dalam proses pembuktian ialah keterangan ahli yang diatur dalam pasal 186 KUHAP. Keterangan ahli yang dimaksudkan di sini dapat juga sudah diberikan pada waktu pemeriksaan oleh penyidik atau penuntut umum yang dituangkan dalam satu bentuk laporan dan dibuat dengan mengingat sumpah pada waktu ia menerima jabatan/pekerjaan tersebut.

Apabila hal itu tidak diberikan pada waktu pemeriksaan oleh penyidik atau penuntut umum, maka pada waktu pemeriksaan di pengadilan diminta untuk memberikan keterangan dan dicatat dalam berita acara pemeriksaan. Keterangan tersebut diberikan setelah ia mengucapkan sumpah atau janji di hadapan sidang mengenai kebenaran keterangan sebagai saksi ahli. Sumpah atau janji yang diucapkan di muka sidang mengenai kebenaran keterangannya yang diberikan sebagai saksi ahli (expert wittness) ini harus dibedakan dengan sumpah atau janji yang diucapkan pada waktu menerima jabatan/pekerjaan (sumpah jabatan). Keterangan ahli yang dimaksudkan oleh pasal 186 KUHAP tersebut bila dikaitkan dengan hubungan dokter dan pasien dapat dituangkan dalam bentuk tertulis maupun lisan. Keterangan ahli yang wujudnya tertulis dapat berupa rekam medis. ${ }^{16}$

Kiranya perlu ditegaskan di sini bahwa sebelum lahirnya Permenkes RI Nomor 749a/Menkes/Per/XII/1989 sebagaimana telah diubah dengan Permenkes RI Nomor 269/ Menkes/Per/III/2008 tentang Rekam Medis, rekam medis sudah merupakan suatu

\footnotetext{
${ }^{14}$ R. Subekti, op. cit., hlm. 22.

15 Hermien Hadiati Koeswadji, "Kendala Yuridis dalam Pembuktian Kesalahan/ Kelalaian dalam Melaksanakan Profesi Medik”, Makalah, Seminar Hospital Management \& Health Law Issues, Karawaci, 25 Juli 1997, hlm. 19; Lihat juga pasal 183 KUHAP.

16 Ibid., hlm. 19-20.
} 
kebiasaan dalam dunia kesehatan (kedokteran), hanya saat itu belum menjadi suatu kewajiban bagi dokter atau Rumah Sakit untuk membuat dan menyimpannya. Dengan lahirnya Permenkes tersebut, berarti pembuatan rekam medis bagi dokter atau Rumah Sakit merupakan suatu kewajiban yang sifatnya imperatif.

Isi rekam medis adalah milik pasien dan wajib dijaga kerahasiannya oleh dokter atau Rumah Sakit. Pemaparan isi rekam medis hanya boleh dilakukan oleh dokter yang merawat dengan izin tertulis dari pasien. Sifat kerahasiaan rekam medis ini perlu diperhatikan, karena menyangkut hak pasien. Apabila isi rekam medis dipaparkan tanpa izin pasien, maka pasien yang merasa dirugikan akibat pemaparan itu dapat menuntut atau menggugat pihak yang memaparkan itu di pengadilan.

Untuk kepentingan pembuktian di pengadilan, dokter yang bersangkutan dapat memberikan fotokopi rekam medis di samping kesimpulannya. Dalam hal demikian, penyidik dengan kuasa tertulis dari pasien atau permintaan pejabat yang berwenang melakukan penyidikan, dapat meminta fotokopi dan kesimpulan rekam medis. Dalam hal pasien dirawat di Rumah Sakit, maka permintaan pemaparan fotokopi rekam medis ditujukan Kepada kepala Rumah Sakit di mana pasien dirawat. Inilah fungsi rekam medis sebagai alat bukti di pengadilan berdasarkan pasal 10 Permenkes tersebut.

Selanjutnya, mengenai kedudukan rekam medis sebagai alat bukti di pengadilan sifatnya tidak mengikat bagi hakim. Artinya, rekam medis merupakan alat bukti bebas, di mana hakim tidak harus percaya tentang kebenaran isi rekam medis; ia boleh yakin atau tidak, tergantung pada penilaian hakim itu sendiri. Karena itu, dalam hukum pidana Indonesia berlaku asas pembuktian negatif, di samping asas "unus testis nullus testis". Hal ini berarti bahwa di satu segi rekam medis dapat digunakan sebagai dasar untuk membuktikan ada/tidaknya kesalahan atau kelalaian dokter dalam melaksanakan profesi, dan dari segi lain rekam medis dapat digunakan sebagai dasar pembelaan atau perlindungan hukum bagi dokter terhadap gugatan atau tuntutan yang diajukan kepadanya. Dengan demikian, penggunaan rekam medis sebagai alat bukti di pengadilan hanyalah dimungkinkan apabila para pihak (dokter, pasien, dan penuntut umum) mengajukan rekam medis sebagai alat bukti untuk menemukan kebenaran materiil dan memperjelas ada atau tidak adanya kesalahan atau kelalaian dokter dalam menjalankan profesinya. ${ }^{17}$

Di samping itu, yang terpenting ialah bahwa rekam medis yang merupakan catatan mengenai dilakukannya tindakan medis tertentu itu secara implisit juga mengandung

17 Ibid., hlm. 21. 
Persetujuan Tindakan Medik (Pertindik) yang didasarkan pada informed consent, karena tindakan medis tertentu itu tidak akan dilakukan oleh dokter apabila tanpa adanya persetujuan untuk melakukan tindakan tertentu dari pasien.

Dengan demikian, rekam medis merupakan alat bukti bahwa dokter telah mengupayakan semaksimal mungkin suatu transaksi terapetik melalui tahapan proses pelayanan kesehatan sampai kepada suatu pilihan terapi yang dipandang paling tepat bagi pasien yang berupa tindakan medis tertentu. Sebaliknya, bagi pasien, rekam medis merupakan alat bukti yang dapat digunakan sebagai dasar apakah tindakan medis tertentu yang dilakukan oleh dokter terhadapnya itu sudah sesuai dengan standar operasional prosedur (SOP) profesi dokter. Oleh karena itu, semakin lengkap isi rekam medis semakin kuat fungsinya sebagai alat bukti yang dapat memberikan perlindungan hukum bagi dokter.

Sebagaimana telah disebutkan di atas, menurut pasal 184 KUHAP, ada 5 (lima) macam alat bukti, yaitu: keterangan saksi; keterangan ahli; surat; petunjuk; dan

keterangan terdakwa. Dilihat dari kelima macam alat bukti menurut KUHAP, rekam medis itu termasuk kategori alat bukti keterangan saksi, keterangan ahli, atau surat?

Keterangan saksi, menurut pasal 185 ayat (1) KUHAP, ialah apa yang saksi nyatakan di sidang pengadilan. Dalam hukum (acara) pidana berlaku asas unus testis nullus testis (satu saksi bukanlah saksi), artinya keterangan yang hanya diberikan oleh satu orang saksi tanpa ada bukti yang lain tidaklah cukup untuk dijadikan dasar untuk menyatakan ada atau tidaknya kesalahan atau kelalaian seseorang. Kesaksian itu baru bernilai apabila didukung oleh alat bukti lain yang sah, seperti keterangan ahli.

Keterangan ahli, menurut pasal 186 KUHAP ialah apa yang seorang ahli nyatakan di sidang pengadilan. Dalam hubungan dokter dan pasien, keterangan ahli yang dimaksudkan oleh pasal 186 KUHAP dapat dituangkan dalam bentuk tertulis maupun tidak tertulis (lisan). Keterangan ahli yang wujudnya tertulis dapat berupa rekam medis (Medical Record) yang dari segi formil merupakan himpunan catatan mengenai hal-hal yang terkait dengan riwayat perjalanan penyakit dan pengobatan atau perawatan pasien. Sedangkan dari segi materiil, isi rekam medis meliputi identitas, diagnosis, riwayat pemeriksaan, dan riwayat pengobatan. Hal ini secara eksplisit diatur pada pasal 3 dan pasal 10 Permenkes RI Nomor 269/Menkes/Per/III/2008 tentang Rekam Medis.

Adanya keharusan bagi saksi ahli untuk mengucapkan sumpah atau janji akan memberikan keterangan yang sebaik-baiknya dan yang sebenar-benarnya menurut pengetahuan dalam bidang keahliannya itu dapat berlaku bagi dokter ahli kedokteran 
kehakiman atau dokter atau ahli lainnya, merupakan hal yang wajib demi keadilan diatur dalam pasal 179 ayat (1) dan (2) KUHAP. Bahkan, bila hakim yakin, karena keterangan ahli mempunyai nilai kekuatan pembuktian bebas, maka hakim bebas menilai dan tidak ada keharusan untuk menerima kebenaran keterangan ahli yang diberikan oleh saksi ahli itu. Oleh karena itu, bila hakim kurang yakin maka ia dapat meminta keterangan ahli lain, dan bahkan dimungkinkan untuk mengadakan penelitian ulang dengan komposisi personal yang berbeda dari instansi lain yang mempunyai kewenangan untuk itu (pasal 180 ayat (1) sampai dengan ayat (4) KUHAP).

Mengenai alat bukti surat, menurut pasal 187 KUHAP, adalah surat-surat yang dibuat oleh pejabat-pejabat resmi yang berbentuk berita acara, akte, surat keterangan atau surat lain yang mempunyai kaitan dengan perkara yang disidangkan. Syarat mutlak untuk menentukan dapat atau tidaknya surat dikategorikan sebagai alat bukti ialah surat tersebut harus dibuat di atas sumpah jabatan atau dikuatkan dengan sumpah. Ketentuan tersebut dimaksudkan agar para pejabat yang mempunyai wewenang untuk membuat surat itu tidak perlu menghadap sendiri di pengadilan. Karena surat-surat yang mereka tanda tangani berdasarkan sumpah jabatan itu cukup dibacakan di persidangan dan kekuatan pembuktiannya sama dengan apabila mereka datang sendiri dan mengatakan secara lisan di muka sidang. ${ }^{18}$

Berdasarkan uraian tersebut di atas, dapatlah disimpulkan bahwa rekam medis sebagai alat bukti mempunyai fungsi ganda, yaitu: pertama, sebagai alat bukti keterangan ahli yang dituangkan dalam bentuk tertulis berdasarkan pasal 186 dan 187 KUHAP, dan kedua, sebagai alat bukti surat berdasarkan pasal 187 KUHAP.

Secara materiil, rekam medis baik sebagai alat bukti keterangan ahli maupun sebagai alat bukti surat merupakan alat bukti bebas. Akan tetapi, secara formil, surat sebagai alat bukti dalam bentuk rekam medis merupakan alat bukti yang sempurna. Ini berarti, bahwa dari satu segi rekam medis sebagai alat bukti surat mempunyai kekuatan pembuktian berdasarkan Peraturan Pemerintah RI Nomor 26 tahun 1960 tentang Lafal Sumpah Dokter, dan dari segi lain rekam medis sebagai alat bukti memenuhi unsur-unsur yang disyaratkan oleh pasal 187 KUHAP, yaitu bahwa apa yang ditulis oleh dokter sebagai isi rekam medis berdasarkan apa yang ia alami, dengar, dan lihat sendiri. Dengan demikian, dapat disimpulkan bahwa dengan keluarnya Permenkes RI Nomor 749a/Menkes/Per/XII/1989 sebagaimana diubah dengan Permenkes RI Nomor 269/Menkes/Per/III/2008 tentang Rekam

18 Ibid., hlm. 23. 
Medis merupakan pelengkap bagi KUHAP mengenai alat bukti yang dapat digunakan dalam menyelesaikan kasus-kasus dimana dokter merupakan salah satu pihak dalam hubungan pelayanan medis (transaksi terapeutik) dengan pasien.

\section{KESIMPULAN}

Berdasarkan analisis masalah tersebut di atas, maka dapat disimpulkan sebagai berikut:

1. Rekam medis adalah berkas yang berisi catatan dan dokumen tentang identitas pasien, pemeriksaan, pengobatan, tindakan dan pelayanan lain yang telah diberikan kepada pasien.

2. Secara formil, rekam medis sebagai alat bukti mempunyai fungsi ganda, yaitu: pertama, sebagai alat bukti keterangan ahli dalam bentuk tertulis berdasarkan pasal 186 dan 187 KUHAP, dan kedua, sebagai alat bukti surat berdasarkan pasal 187 KUHAP. Kehadiran Permenkes RI Nomor 269/Menkes/Per/III/2008 merupakan pelengkap bagi KUHAP mengenai alat bukti rekam medis yang dapat digunakan dalam menyelesaikan kasus terkait transaksi terapeutik (hubungan pelayanan medis) antara dokter dan pasien.

3. Secara materiil kedudukan rekam medis sebagai alat bukti, baik sebagai alat bukti keterangan ahli maupun alat bukti surat merupakan alat bukti bebas, artinya hakim bebas (tidak terikat) untuk meyakini kebenaran isi rekam medis sebagai alat bukti, semua bergantung sepenuhnya pada penilaian hakim.

\section{DAFTAR PUSTAKA}

\section{Peraturan Perundang-undangan}

Kitab Undang-undang Hukum Perdata (Burgerlijk Wetboek)

Undang-undang Nomor 8 Tahun 1981 tentang Acara Pidana (KUHAP)

Undang-undang Nomor 29 Tahun 2004 tentang Praktik Kedokteran

Peraturan Pemerintah RI Nomor 26 tahun 1960 tentang Lafal Sumpah Dokter

Peraturan Menteri Kesehatan RI Nomor 749a/Menkes/Per/XII/1989 tentang Rekam Medis

Peraturan Menteri Kesehatan RI Nomor 269/Menkes/Per/III/2008 tentang Rekam Medis

\section{Buku}

Fred Ameln, 1991, Kapita Selekta Hukum Kedokteran, Grafikatama, Jakarta,

Francoeur, Robert T., 1983, Biomedical Ethics: A Guide to Decision Making, John Wiley \& Sons, New York, Chicester, Brisbane, Toronto, Singapore.

Gunadi, J., 2010, Hukum Medik (Medical Law), Cet. Ke-4, Balai Penerbit FKUI, Jakarta.

Hendrik, 2011, Etika dan Hukum Kesehatan, Penerbit Buku Kedokteran EGC, Jakarta.

Hermien Hadiati Koeswadji, 1984, Hukum dan Masalah Medik, Bagian Pertama, Airlangga University Press, Surabaya.

--------, 1998, Hukum Kedokteran (Studi tentang Hubungan Hukum dalam mana 
Dokter sebagai Salah Satu Pihak), Citra Aditya Bakti, Bandung.

------, 1997, “Kendala Yuridis dalam Pembuktian Kesalahan/Kelalaian dalam Melaksanakan Profesi Medik", Makalah, Seminar Hospital Management \& Health Law Issues, Karawaci.

Kadir Sanusi, 1995 "Segi-segi Tanggungjawab Hukum Rumah Sakit dalam Kaitannya dengan Hubungan Dokter-Pasien", Disertasi, Program Pascasarjana Unair, Surabaya.

Moh. Hatta, 2013, Hukum Kesehatan dan Sengketa Medik, Liberty, Yogyakarta,

Rio Christiawan, 2003, Aspek Hukum Kesehatan, Universitas Atmajaya, Yogyakarta,

Syahrul Machmud, 2008, Penegakan Hukum dan Perlindungan Hukum bagi Dokter yang Diduga Melakukan Medikal Malpraktek, Mandar Maju, Bandung,

Soerjono Soekanto dan Herkutanto, 1987, Pengantar Hukum Kesehatan, Remaja Karya, Bandung.

Subekti, R., 1983, Hukum Pembuktian, Pradnya Paramita, Jakarta.

-------, 1984, Hukum Perjanjian, Internusa, Jakarta,

Sutarno, 2014, Hukum Kesehatan: Euthanasia, Keadilan dan Hukum Positif di Indonesia, Setara Press, Malang

Yusuf Hanafiah, M., dan Amri Amir, 1999, Etika Kedokteran dan Hukum Kesehatan, Buku Kedokteran EGC, Jakarta. 